\title{
A perinatalis hospice-palliatív gondozás lehetőségei és kihívásai
}

\author{
Zsák Éva - Hegedûs Katalin dr.
}

Semmelweis Egyetem, Általános Orvostudományi Kar, Magatartástudományi Intézet, Budapest

\begin{abstract}
A perinatalis hospice-ellátás a gyermekgyógyászati palliatív ellátás egy speciális formája: elsősorban a terhesség alatt megállapított fejlődési rendellenességek esetében, a várandósgondozásban megvalósuló holisztikus szemléletú, az érintett családokra vonatkozó testi, lelki és szellemi gondozás. Célunk annak vizsgálata, hogy az elérhető szakmai irányelvek alapján hogyan valósítható meg és milyen lehetőségeket nyújthat a perinatalis hospice-palliatív gondozás. Néhány példán keresztül bemutatjuk az elsősorban angolszász területekról származó szakmai irányelveket, protokollokat, valamint a jó gyakorlat néhány példáját. A perinatalis hospice kiemelten nehéz ellátási terület a szakmai és emberi nehézségeket illetően. Kiindulási pontot jelentenek a standardizált, konszenzuson alapuló irányelvek, amelyek részletezik az ellátás sajátosságait és azt is, hogy milyen feltételek szükségesek a biztosításához, emellett pedig jelentős segítséget nyújthatnak a közremúködő szakmák közötti kommunikációs és koordinációs folyamatokban. Szupportív szakmai képzési programok során lehetőség adódhat a nehézséget jelentő helyzetek felismerésére, valamint a megoldások keresésére is. A továbbképzés a palliatív ellátásban és a megfelelő kommunikációban kompetenciafejlesztést jelent a szakmai feladatok ellátásában.
\end{abstract}

Orv Hetil. 2020; 161(12): 452-457.

Kulcsszavak: perinatalis időszak, hospice-palliatív ellátás, perinatalis veszteség, neonatológia

\section{Possibilities and challenges of perinatal hospice-palliative care}

Perinatal hospice care is a special form of paediatric palliative care, with a focus on prenatally diagnosed malformation, providing physical, psychological and mental support with a holistic approach for the families. Our aim was to analyse how perinatal hospice-palliative care can be implemented and what opportunities it may provide on the basis of available professional guidelines. We introduce study and analysis of the professional guidelines and protocols, mainly from Anglo-Saxon countries, and describe some examples of best practices. Perinatal hospice is a specially demanding care regarding professional and personal challenges. Standardised guidelines based on consensus can serve as starting points, describing proper care and its conditions. Moreover, they can facilitate communication and coordinative processes between the collaborating specialists. Challenging conditions and possible solutions to them can be identified during supportive formative courses. Continuous formation means competency development in palliative care as well as in adequate communication.

Keywords: perinatal period, hospice-palliative care, perinatal loss, neonatology

Zsák É, Hegedûs K. [Possibilities and challenges of perinatal hospice-palliative care]. Orv Hetil. 2020; 161(12): $452-457$.

(Beérkezett: 2019. szeptember 13.; elfogadva: 2019. december 3.)

\section{Rövidítések}

HSJD = Hospital Sant Joan de Déu (Barcelona); NIC = neonatalis intenzív centrum; NHS $=($ National Health Service $)$ az Egyesült Királyság Egészségügyi Szolgálata

\section{A perinatalis hospice jelentése}

A perinatalis hospice-ellátás a gyermekgyógyászati palliatív ellátás egy speciális, az utóbbi évtizedben kialakított formája. A felnőtt [1, 2] és gyermek [3] palliatív ellátáshoz hasonlóan célja az elörehaladott, életet veszélyeztetô állapotú betegek és hozzátartozóik holisztikus szemléletű, testi, lelki és szellemi gondozása, a lehető legjobb életminőséget szem előtt tartva, a gyermekgyógyászati palliatív ellátás standardjainak megfelelően [4]. A kifejezés megalkotója Byron Calhoun egyesült államokbeli szülész-nőgyógyász, aki 1997-ben közzétett tanulmányában alkalmazta először a kifejezést [5]. 
A perinatalis hospice a terhesség alatt megállapított fejlődési rendellenességek esetében, a várandósgondozásban megvalósuló szakorvosi, szakpszichológusi, szociális, lelki és ehhez kapcsolódó szakmai és emberi kísérést jelenti. Ez az egész családra fókuszáló ellátás alternatívát nyújthat azon családok számára, akik nem szeretnék a magzatnak az élettel korlátozottan összeegyeztethető rendellenes fejlődése esetében a várandósság befejezését, akár már egy korán felállított diagnózis esetében sem. Az ellátás fókuszában az egész család áll, akiket multidiszciplináris team vesz körül ezen időszak alatt, támogatva a diagnózisalkotás után a család döntéseit és azok feltételeinek megteremtését [6-8].

A tágabb értelmezésben ugyanakkor a perinatalis hospice magában foglalja a praenatalis időszakban bekövetkező korai veszteségek és a postnatalis/neonatalis ellátásban - extrém koraszülöttség esetén - megvalósuló palliatív gondozást is, azokra a nehézségekre összpontosítva, amelyek az egyes periódusokat jellemzik. A praenatalis időszakban ez elsősorban a veszteség, gyász kísérését jelenti, míg a későbbiekben a szüléshez, koraszüléshez és a NIC-hez kapcsolodó ellátási feladatokat is érinti, a veszteségkíséréssel együtt. A felnőtt hospice-palliatív ellátáshoz hasonlóan a cél a lehető legjobb életminőség biztosítása az adott körülmények között: élettel megtölteni a rendelkezésre álló napokat, azzal a különbséggel, hogy az életkezdet és az életvég a perinatalis hospice-ban alig vagy szinte nem is válik el egymástól. Az időben ezért jelentősen korlátozott életszakaszban a gyermeket szülői szeretet és az állapotának megfelelő ellátás veszi körül, míg a szülőpár megélheti szülőségét annak teljes minőségében.

\section{Módszer}

Jóllehet a perinatalis hospice-palliatív ellátás különböző országokban ismert, elérhető szakmai irányelvek mégis elsősorban az angolszász területeken találhatók. A South Central Neonatal Network Guideline 2012. évi [9] és a Chelsea and Westminster Hospital, NHS 2014. évi szakmai irányelvei Nagy-Britanniában [10], illetve a NyugatAusztráliában érvényben lévő West Australian Cancer and Palliative Care Network Perinatal Palliative Care modellje 2015-ből [11] adnak átfogó képet a gondozási modellról és az egyes jellegzetességekről. Tanulmányunk célja ezen protokollok tanulmányozása, elemzése, rámutatva arra, hogy adaptációjuk hogyan lehet iránymutató az ellátás hazai megvalósításában.

\section{Eredmények}

\section{Elérhetô" szakmai irányelvek}

Jól érzékelteti az ellátási forma újszerüségét, hogy a 2009-ben íródott, Írországban érvényes gyermekgyógyászati palliatív protokoll még a perinatalis területen kifejezetten alkalmazható irányelvek hiányáról tesz kije- lentést (Palliative Care for Children with Life-Limiting Conditions in Ireland). Ugyanakkor azt is megállapítja, hogy a szakmai irányelvek kidolgozása alatti időszakban Írországban a teljes, gyermekkorban bekövetkező halálozás több mint 70\%-a az elsô életév vége előtt fordul elő, és ezekből körülbelül 50\% a születést követő első héten történik. Magyarországon a 18 év alatti halálozások kb. 50\%-a következik be az első életévben. 2017-ben 332 csecsemőhalált regisztráltak. Ezeknek körülbelül $40 \%$-a a születést követő első hét végéig következik be [12].

Kidolgozott perinatalis palliatív protokollok 2010 után jelentek meg, és jellemzően regionális, nem pedig országosan érvényes útmutatások. Erre példaként szerepelhetnek a következők: a South Central Neonatal Network Guideline 2012. évi [9], a Chelsea and Westminster Hospital, NHS 2014. évi szakmai irányelvei Nagy Britanniában [10], illetve a Nyugat-Ausztráliában érvényben lévő WA Cancer and Palliative Care Network Perinatal Palliative Care modellje 2015-ból [11], amelyek a perinatalis palliatív gondozás különféle lehetőségeire, jellegzetességeire hívják fel a figyelmet, ezzel segítve az ellátásban dolgozó szakemberek munkáját. Nagy-Britanniában szinte egyedüliként ugyanakkor létezik országos szinten érvényes ajánlás is, amely az ellátás foobb irányvonalait hivatott felvázolni [13].

A specializált perinatalis hospice-ellátás alapelveként a 'Right care, Right time, Right team, Right place' áll központi helyen a nyugat-ausztrál irányelvekben, azaz a gyermek és családja az igényeinek megfelelő fizikai, spirituális, pszichoszociális és kulturális gondozásban kell, hogy részesüljön, a teljes perinatalis időszakban. A gondozást olyan multidiszciplináris szakmai team biztosítja, amely megfelelő szakmai hozzáértéssel rendelkezik mind az anyai és neonatalis, mind pedig a palliatív ellátási területeken. A megfelelő ellátáshoz szükséges különböző szakterületek sikeres együttmúködését az egyedi eseteket kísérő, koordináló szakember jelenléte biztosítja. Az ellátás színterének elsődlegesen meghatározó tényezője bármely olyan helyszín lehet, amely a gyermek és az anya megfelelő szintű ellátását biztosítani képes [11].

Hasonlóképpen, a nyugat-ausztrál gondozási modell mutat rá a komplex értelmezés szerinti lehetséges bemeneti útvonalakra a perinatalis palliatív gondozásba való bekerüléshez (1. ábra).

A brit Royal College of Paediatrics and Child Health és a Chelsea and Westminster Hospital által 2014-ben publikált gyakorlati irányelv (Practical guidance for the management of palliative care on neonatal units) [10] a palliatív ellátás kritériumai közé sorolja a fentieken túl azt a postnatalis állapotot is, amikor a palliatív ellátás szolgálja a leginkább a gyermek érdekeit, mert minden egyéb ellátás elviselhetetlen fájdalmat okoz a gyermeknek. Ennek a protokollnak a további sajátossága, hogy kiemeli az ellátásban részt vevő szakemberek mentális és lelki egészségének megőrzéséhez szükséges szupportív támogatás fontosságát, valamint összegyưjti és listázza 


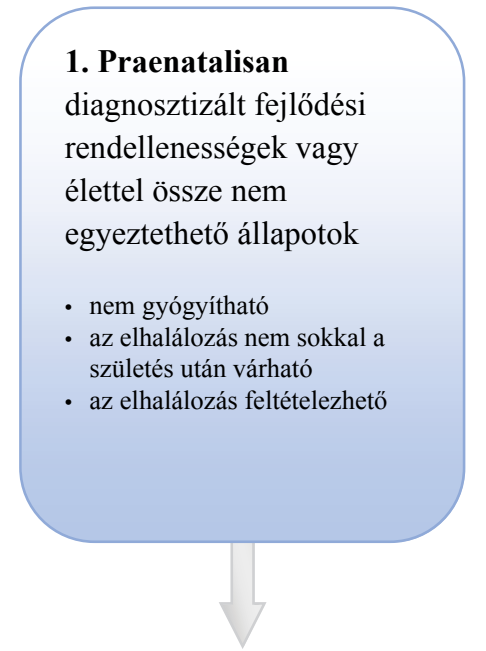

2. 'Previable', extrém, terminus elötti

koraszülés, amelynél a túlélési esélyek súlyosan korlátozottak

- az újraélesztés nem szolgálja a gyermek érdekét

- a gyermek életképességei nem megfelelőek

- a gyermek nem rendelkezik a túléléshez szükséges funkciókkal

\section{Postnatalisan}

diagnosztizált fejlődési

rendellenességek vagy

élettel össze nem

egyeztethető állapotok

- preanatalisan fel nem ismerhetö

- váratlan

- neonatalis osztályon felismert

- multidiszciplináris team diagnózisa

Az ezen belépési pontokhoz tartozó referencia ellátási területek:

\section{1. szülészet és neonatológia}

A perinatalis palliatív gondozást az azonosított esetekhez az arra specializálódott szakember kíséri tovább.

2. szülészet, neonatológia és koraszülöttosztályok
3. (neonatológiai)

gyermekgyógyászati osztály

Egyénre szabott gondozási terv kialakítása

Perinatalis Palliatív Gondozási Terv

A perinatalis veszteséggel foglalkozó szolgálattal való kapcsolatfelvétel
A helyi ellátásban való részvétel, konzultáció és együttmüködés

\begin{tabular}{l|l} 
1. ábra & A perinatalis palliatív gondozásba való bekerülés lehetséges pontjai
\end{tabular}

(Az ábra eredetije: WA PPC Model of Care Fig. 2. Entry points into perinatal palliative care)

azokat a szervezeteket, amelyek a veszteséget elszenvedő pároknak további támogatást tudnak nyújtani, túl azokon a veszteségben nyújtott szolgáltatásokon - veszteségkísérés, pszichés és szupportív támogatás -, amelyek a palliatív gondozás részei.

A szintén brit South Central Neonatal Network Guideline-ban 2012-ből [9] az újszülöttellátásban alkalmazható komfortellátás (comfort care) és fájdalomcsillapítás részletein túl az életvégre vonatkozó ellátás előzetes tervezésének (Advance Care Planning) fontossága [14], a szervadományozás lehetősége (például szívbillentyúk esetén) szerepel, valamint a gyermek elhunyta utáni teendőkre és emlékezési lehetőségekre hívják fel a figyel- met. Az előzetesen egyeztetett és megbeszélt ápolási terv (Advance Care Plan) elengedhetetlen dokumentum, amely tartalmazza az újraélesztésre, a gyermek állapotának rohamos romlására vonatkozó teendőket éppúgy, mint a család kéréseit és annak a teamtagnak az elérhetőségét, aki a gyermek ápolásáért felelős. A gyermek állapotának függvényében szükséges áttekinteni a tervet, amely az aktív gyógykezelés és a szupportív, palliatív ellátás közötti átmenetekre egyformán kiterjed. A tervet illető esetleges módosításokról fontos tájékoztatni a gyermek gondozásában részt vevő szakembereket az ellátás minden szintjén. Ennek a tervnek egy példánya állandóan a szülőknél kell, hogy legyen [9]. 
A család közös emlékeinek megteremtéséhez részletes és aprólékos listát kínál a lehetőségekkel, kiemelve, hogy az az idő, amíg a gyermekkel családként lehetnek együtt, jelentősen korlátozott, nem adódik erre többet sem idejük, sem lehetőségük, éppen ezért felbecsülhetetlen minden pillanat és közös emlék. A megfogalmazott javaslatok között az alábbiak szerepelnek (2. ábra):

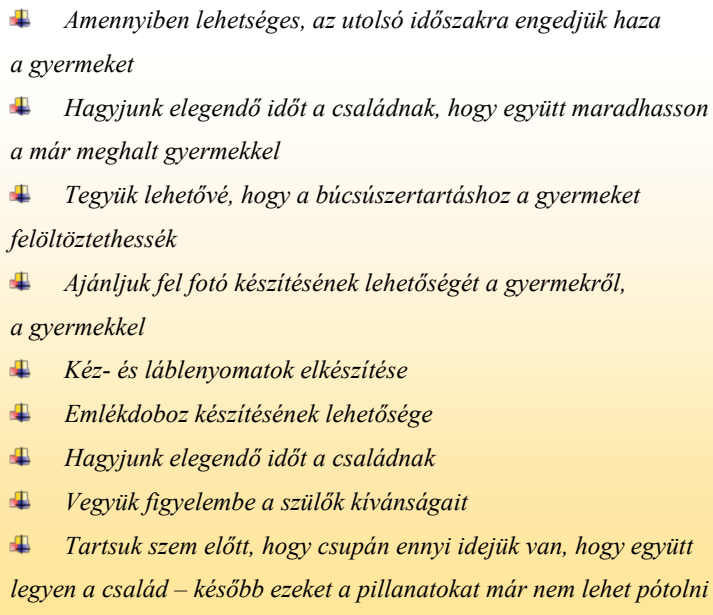

2. ábra

| Emlékezési és búcsúzási lehetőségek

(Forrás: South Central Neonatal Network Guideline for Neonatal Palliative Care: 5.0 Offering Choices and Creating Memories

Mindhárom tanulmányozott dokumentum hangsúlyozza a kommunikáció fontosságát, azokat a kritikus pontokat, amelyekre a gondozást végző szakembereknek figyelmet kell fordítaniuk a perinatalis palliatív ellátásban részt vevő családokkal való beszélgetések során.

A kommunikációs panel elemei tartalmazzák:

- a folyamatos párbeszédet/interakciót, még nagyon komplex/komplikált esetekben is (például ikerterhességben az egyik gyermek elhalálozása, a másik túlélése),

- az érintett szakterületek képviselői és a szülők közötti egyeztetést a gondozási terv kialakításakor,

- a lehetőséget a további megbeszélésekre,

- a gondosan megválasztott kifejezések használatát (például „palliatív gondozás” és „comfort care” a „gyógykezelés megszüntetése” helyett,

- a nyomtatott információs anyagokat.

\section{A már létezö megoldások, jó gyakorlatok}

Az Egyesült Államokban már nemzeti és nemzetközi referencia-adatbázis is létezik azokról az intézményekról, amelyekben a perinatalis palliatív és hospice-gondozás megvalósul [15]. Az országban nemzeti szinten kialakított és elfogadott irányelv nem férhető hozzá, a több mint 300 múködő perinatalis palliatív program az adottságainak megfelelően alakítja ki saját irányelveit [16].
Az alábbiakban néhány intézményt és gyakorlatukat szeretnénk bemutatni. Észak-Amerikában jelentős például a New York-i Presbyterian/Morgan Stanley Children's Hospital Neonatal Comfort Care programja, amely praenatalis támogatást is nyújt, angol és spanyol nyelven is. Az intézmény az alábbi célokat fogalmazza meg [17]:

1) A gyermek jólléte

Bármilyen rövidre szabott legyen is, minden gyermek élete értékes, fontos. Ezért gondoskodásunk fókusza a gyermek jólléte.

\section{2) Képzés}

Elkötelezettek vagyunk abban, hogy kimagasló szintű képzésben részesítsük az egészségügyi szakembereket, valamint hogy a legfrissebb kutatási eredményekhez igazodva biztosítsuk a perinatalis ellátás magas színvonalát.

3) A gondozás folytonossága

Elkísérjük a családot az út minden állomásán, a diagnózistól a születésig és azon túl is, a fizikai, érzelmi és spirituális szükségletek kielégítésével.

4) Csapatmunka

Csoportunk tagjainak egyéni képességeit ötvözve egyedülálló gondoskodást, odafigyelést nyújtunk bármely, korlátozott életkilátásokkal született gyermeknek és családjának.

$\mathrm{Az}$ interdiszciplináris szakemberi csoport kétszintű együttmúködésen alapszik. Az ellátást végzők bázistagjai a neonatológus, a klinikai ápolási koordinátor, a szociális munkás és a programvezető. Az ő munkájukat a nagyobb, perinatalis palliatív gondozási csoportban szülész-nőgyógyász, pszichológus, gyermekspecialista (védőnő), kórházi lelkész és szülésznő egészíti ki, teszi teljessé. Vállalásuk szerint a diagnózistól a születésig és azon túl is kísérik az érintett családokat, személyre szabott orvosi kezelési terv alapján, hogy az optimális körülményeket biztosíthassák a gyermek és a szülők közötti kötődés, szeretet és öröm megéléséhez. A szakembereket speciális képzési programok révén - Comfort Care Training - készítik fel és támogatják hivatásukban.

Európában az olasz nonprofit egyesület, a La Quercia Millenaria ernyőszervezet nyújt a katolikus értékekkel összhangban szakmai-bioetikai hátteret és szolgál alapintézményként az országban múködő, palliatív gondozást biztosító perinatalis hospice-oknak [18].

Alapító dokumentumukban fogalmazzák meg a következőket:

1) A várandósság teljes időszaka alatt támogatják azokat a családokat, amelyekben a várt gyermeknél az életkilátásokat jelentősen korlátozó súlyos betegséget, fejlődési rendellenességet diagnosztizálnak.

2) Az így nyújtott támogatás a terhesség végigkísérését jelenti a gyermek megszületéséig.

3) A katolikus egyház szellemében orvosi, pszichés és spirituális gondozást nyújtanak vizsgálatok, diagnózisok és terápiás javaslatok formájában.

4) A hozzájuk forduló szülők támogatást kaphatnak azoktól a családoktól is, amelyek már korábban kapcso- 
latba kerültek az egyesülettel, és részt vesznek a szupportív munkában.

Az egyesülettel együttmúködő intézmények között van például a mantovai Azienda Ospedaliera Carlo Poma, amely a fenti elvek alapján formálta meg szakmai perinatalis hospice-programját, és részt vesz az egyesület nyújtotta képzéseken is.

A Barcelonában található Hospital Sant Joan de Déu (HSJD) Hospice Perinatal Program protokollja szerint a pediátriai palliatív team révén a gyermek otthoni gondozása is biztosított. A megfelelően képzett, felkészített szakemberek a gyermekek és családjaik testi, pszichés, szociális, spirituális és kulturális szükségleteinek ellátását végzik.

Magyarországon a Semmelweis Egyetem II. Nőgyógyászati Klinikáján múködő NIC-ben kezdeményezték először ennek az ellátási formának a megvalósítását, kérve az egyetem Magatartástudományi Intézetében múködő Tanatológiai Munkacsoport szakmai támogatását, így ez az intézmény is szerepel a nemzetközi listán. A kezdeményezés révén a Szakmai Kollégiumok Hospice-Palliatív Tagozata is célként fogalmazta meg a perinatalis palliatív gondozás magyarországi elérhetőségének megvalósítását.

A perinatalis hospice egyik formája az újszülöttkori komfortkezelés, a Perinatal Comfort Care, amelynek kidolgozása a már fentebb említett New York-i Presbyterian Kórházban praktizáló olasz dr. Elvira Parravicini nevéhez füződik [19]. Az ellátás célja a palliatív-hospice gondozás egyéni igényekhez való igazítása, személyre szabott és innovatív kezelési mód adása a kicsiny pácienseknek. Tartalmazhat szakorvosi, sebészi megoldásokat, de fókuszában a leginkább a páciensnek a körülményekhez képest való lehetséges legmagasabb szintű jólléte szerepel. Ennek feltételei a családdal való kapcsolat, a megfelelő testhőmérséklet biztosítása, a fizikai szükségletek kielégítése, valamint a megfelelő fájdalomcsillapítás. Ezeken túl szükséges lehet az adott klinikai kondícióknak megfelelő ellátás biztosítása, amelyhez elengedhetetlen az orvosi-szakápolási terv kidolgozása minden esetben. A Perinatal Comfort Care-ben a család minden tagja - a különböző szakemberek révén - részesül a szükségleteinek megfelelő gondozásban, hogy a gyermek rövid életét akár aktívan, szeretettel élhessék meg, és a megfelelő módon búcsúzhassanak el tőle.

\section{Megbeszélés}

A perinatalis hospice-palliatív ellátás megvalósításában biztos hátteret, kiindulási pontot jelenthetnek a standardizált, szakmai konszenzuson alapuló irányelvek és protokollok, amelyek jelentős mértékü segítséget nyújthatnak a közremúködő szakmák közötti kölcsönös kommunikációs és koordinációs folyamatokban a kihívást jelentő esetek során.

Számos nehézség és kihívás rejlik a perinatalis hospiceellátásban, hiszen fokozott szakmai és emberi kihívást jelent a gondozást végzők számára. Annak érdekében, hogy a megélt, nehéz helyzeteket el lehessen viselni, külön figyelmet kell fordítani az érzések, érzelmek, problémák feldolgozására, a szakemberek lelki egészségének megóvására [20, 21]. A szupportív szakmai képzési programok során lehetőség adódhat a motivációk és adott válaszok értelmezésére, definiálására éppúgy, mint az ellátási módok újrakeretezésére. Fontos azonosítanunk a nehézséget okozó tényezőket és a körülményeikhez igazított, optimális megoldási módokat. A szupportív gondozás érdekében fel kell készülnünk a személyes fájdalmat is hordozó helyzetek kommunikációs nehézségeire, azok megoldási lehetőségeire.

\section{Következtetés}

A perinatalis palliatív gondozásban jelen lévő érzelmi és pszichés distressz miatt szükséges lenne az egyes eseteket követő megbeszélés egy erre felkészült teamtag vagy akár egy külső facilitátor részvételével, amely lehetőséget adna a csoportnak a részletek megbeszélésére, a közös munka eredményeinek kiemelésére és a nehézségekhez esetleges megoldási javaslatokra. Ajánlott, hogy az érintett szakemberek igénybe vehessenek klinikai szakpszichológusi és/vagy spirituális támogatást, hiszen ezek útján az egyéni megküzdés erősödik. A folyamatos továbbképzés mind a palliatív ellátásban, mind pedig a megfelelő kommunikációban olyan eszközöket jelent a szakmai feladatok ellátásában, amelyek révén már bevált, kipróbált módok válhatnak a szakemberek kompetenciaterületeinek részévé, ezáltal segítve a hivatásukban való magas szintü helytállást [10].

Anyagi támogatás: A közlemény megírása anyagi támogatásban nem részesült.

Szerzői munkamegosztás: Zs. É.: A háttérirodalom összegyüjtése, feldolgozása, a kézirat megírása. H. K.: Szakértői részvétel az eredmények értékelésében és a tanulmány megírása. A cikk végleges változatát mindkét szerző elolvasta és jóváhagyta.

Érdekeltségek: A szerzőknek nincsenek érdekeltségeik.

\section{Irodalom}

[1] Hegedűs K, Lukács M, Schaffer J, et al. Situation, possibilities and difficulties of the hospice and palliative care in Hungary. [A hazai hospice- és palliatív ellátás helyzete, lehetőségei, nehézségei.] Orv Hetil. 2014; 155: 1504-1509. [Hungarian]

[2] Radványi I, Nagy L, Balogh S, et al. Palliative care in non-cancer chronic progressive diseases. [Nem daganatos, krónikus progresszív betegségek palliatív ellátása.] Orv Hetil. 2015; 156: 1703-1709. [Hungarian]

[3] Benyó G, Révész RL, Králik I. Introduction and a case study of the Tábitha Hospice House for children and young adults. [A Tábitha Gyermekhospice Ház múködésének bemutatása és 
esetismertetés.] Kharón Thanatol Szle. 2017; 21(2): 1-16. [Hungarian]

[4] Craig F, Abu-Saad HH, Benini F, et al. IMPaCCT: standards for paediatric palliative care in Europe. Eur J Palliative Care 2007; 14: 109-114. [In Hungarian: IMPaCCT. A gyermekgyógyászati palliatív ellátás európai standardjai. Kharón Thanatol Szle. 2007; 11(3-4): 1-14.]

[5] Calhoun BC, Hoeldtke NJ, Hinson RM, et al. Perinatal hospice: should all centers have this service? Neonatal Netw. 1997; 16: 101-102.

[6] Nyirô J, Hauser P, Zörgő Sz, et al. Difficulties in communication with parents of pediatric cancer patients during the transition to palliative care. [A kommunikáció nehézségei daganatos gyermekek szüleivel a palliatív ellátásra történő áttérés során.] Orv Hetil. 2017; 158: 1175-1181. [Hungarian]

[7] Balaguer A, Martín-Ancel A, Ortigoza-Escobar D, et al. The model of palliative care in the perinatal setting: a review of the literature. BMC Pediatr. 2012; 12: 25.

[8] Kenner C, Press J, Ryan D. Recommendations for palliative and bereavement care in the NICU: a family centered integrative approach. J Perinatol. 2015; 35(Suppl 1): S19-S23.

[9] NSH South Central. Neonatal Network Guideline. Available from: https://www.networks.nhs.uk/nhs-networks/thamesvalley-wessex-neonatal-network/documents/guidelines/ $6.3 .1 \% 20$ kangaroo $\% 20$ care $\% 20$ guideline.pdf [accessed: June 6 , 2019].

[10] Mancini A, Uthaya S, Beardsley C, et al. Practical guidance for the management of palliative care on neonatal units. Chelsea and Westminster Hospital, NHS. February 2014. Available from: https://www.chelwest.nhs.uk/services/childrens-services/neonatal-services/links/Practical-guidance-for-the-management-ofpalliative-care-on-neonatal-units-Feb-2014.pdf [accessed: June $6,2019]$.

[11] Department of Health, Western Australia. Perinatal Palliative Care Model of Care. WA Cancer and Palliative Care Network, Department of Health, Western Australia, Perth, 2015. Available from: https://ww2.health.wa.gov.au/ /media/Files/Corporate/general\%20documents/Health\%20Networks/WA\%20Cancer\%20and\%20Palliative\%20Care/Palliative\%20care/PerinatalPalliative-Care-Model-of-Care.pdf [accessed: June 6, 2019].

[12] Hungarian Central Statistical Office. Information data base. Population. Population Movement. [KSH. Tájékoztatási adatbázis. Népesség, népmozgalom (1941-) 3/3.] Available from: https://www.ksh.hu/docs/hun/xstadat/xstadat_eves/i_ wnt00lc.html [accessed: June 6, 2019]. Hungarian Central Statistical Office. Information data base. Population. Population Movement. Mortality. [KSH. Tájékoztatási adatbázis. Népesség, népmozgalom. Halálozás. Available from: http://statinfo.ksh. hu/Statinfo/haViewer.jsp [accessed: June 6, 2019].

[13] British Association of Perinatal Medicine. A framework for clinical practice in perinatal medicine. Available from: https://www. bapm.org/resources/category/BAPM\%20Frameworks\%20 for\%20Practice [accessed: June 6, 2019].

[14] Busa Cs, Zeller J, Csikós Á. Who should decide at the end of life? International practice of advance care planning and possibilities for adaptation in Hungary. [Ki döntsön az élet végén? Az ellátás előzetes tervezésének nemzetközi gyakorlata és hazai lehetőségei.] Orv Hetil. 2018; 159: 131-140. [Hungarian]

[15] Perinatal Hospice and Palliative Care Programs and Support in United States. Available from: https://www.perinatalhospice. org/list-of-programs [accessed: June 6, 2019].

[16] Cole JC, Moldenhauer JS, Jones TR, et al. A proposed model for perinatal palliative care. J Obstet Gynecol Neonatal Nurs. 2017; 46: 904-911.

[17] Neonatal Comfort Care Program. Available from: http://www. neonatalcomfortcare.com [accessed: June 6, 2019].

[18] La Quercia Millenaria. Perinatal Hospise. Available from: http:// www.laquerciamillenaria.org [accessed: June 6, 2019].

[19] Parravicini E. Curing the incurable: neonatal palliative care as a method. [A gyógyíthatatlanok ellátása: az újszülöttkori komfortkezelés mint módszer.] Kharón Thanatol Szle. 2015; 19(4): 15-21. [Hungarian]

[20] Zsák E, Kovácsné Török Zs, Hegedús K. Analysis of practices actually applied in perinatal and intrauterine infant death, and of their effects on medical personnel. [A perinatalis veszteségek és intrauterin magzati halálozások aktuális szakmai gyakorlatának, valamint a szakemberekre gyakorolt hatásainak vizsgálata.] Orv Hetil. 2015; 156: 1174-1178. [Hungarian]

[21] Révay E, Kegye A, Zana A, et al. The everyday life of survivors. The quality of life of hospice workers. [A túlélók mindennapjai. A hospice ellátásban dolgozók életminősége.] Orv Hetil. 2016; 157: 1000-1006. [Hungarian]

(Zsák Éva, Budapest, Nagyvárad tér 4., 1089 e-mail: zsak.eva@phd.semmelweis-univ.hu)

\section{ÁLLÁSAJÁNLAT}

Tápiószecső Nagyközség Önkormányzata gyermekorvost keres. Nagy gyermeklétszámú, jól karbantartott praxisunk gyermekorvos jelentkezését várja. A praxis azonnal betölthetö.

Az Önkormányzat 3 éven keresztül plusz havi 100000 Ft-ot térít, melyet lakásbérlésre vagy útiköltségre lehet felhasználni.

\section{Érdeklődni telefonon az alábbi számon lehet: \\ Gál Csaba \\ 06203200142}

A cikk a Creative Commons Attribution 4.0 International License (https://creativecommons.org/licenses/by/4.0/) feltételei szerint publikált Open Access közlemény, melynek szellemében a cikk bármilyen médiumban szabadon felhasználható, megosztható és újraközölhető, feltéve, hogy az eredeti szerző és a közlés helye, illetve a CC License linkje és az esetlegesen végrehajtott módositások feltüntetésre kerülnek. (SID_1) 